\title{
Training Development of Teaching Factory Based on Local Wisdom in Vocational High School
}

\author{
Luthfiyah Nurlaela ${ }^{1}$ Ratna Suhartini ${ }^{2 *}$ Ekohariadi $^{3}$ Munoto $^{4}$ \\ Asto Buditjahjanto ${ }^{4}$ Ismet Basuki ${ }^{4}$
}

\begin{abstract}
${ }^{1}$ Home Economic Department, Faculty of Engineering.Postgraduate School, Universitas Negeri Surabaya, Indonesia.
${ }^{2}$ Postgraduate School.Vocational Progam, Universitas Negeri Surabaya, Indonesia.

${ }^{3}$ Informatics Engineering Department Faculty of Engineering, Universitas Negeri Surabaya, Indonesia.

${ }^{4}$ Electrical Engineering Department, Faculty of Engineering, Universitas Negeri Surabaya, Indonesia.
\end{abstract}

${ }^{*}$ Corresponding author. Email: ratnasuhartini@unesa.ac.id

\begin{abstract}
The teaching factory (TEFA) and techno-park programs are an effort to improve learning in schools. Therefore, they can be commensurate with the situation in the industry, both in terms of study time, product standards, and work environment. The production-based learning process to produce products that are worth selling. Products are planned to follow the local potential of the local area and are equivalent to products from the industry. The government launched the teaching factory program, but not all vocational schools carry out teaching factory learning; for various reasons, there are many obstacles. The obstacles experienced by SMKN/S are different. The obstacles faced by schools are a lack of understanding about the teaching factory. The understanding of teaching factory management is minimal, such as management, production processes, lab workshops, product planning, and marketing. Schools that implement teaching factories are still minimal. There are even schools that carry out teaching factories only once. With this background, training is needed. The research objectives are 1) To describe the training of teaching factory development at SMKN/S Regency, 2) To plan products from local potentials 3) To describe the management of potential products as learning outcomes that can be sold. The research sample is vocational school teachers in East Java. Methods of data collection using a questionnaire. Data analysis using the description. The results showed: the teaching factory development training was carried out optimally, the participants were very enthusiastic, and attendance was $100 \%$, the material was well absorbed. The planned product does not refer to local products. The curriculum and previous products still dominate the product. Management of potential products requires the involvement of industry, local government policies, and local communities.
\end{abstract}

Keywords: Development, Local Wisdom, Teaching Factory, Training.

\section{BACKGROUND OF STUDY}

Vocational schools are expected to be at the forefront of developing and processing regional potentials to become regional economic drivers, which will ultimately impact national economic development. Based on the description above, two potentials can be packaged in a study to support the vocational revitalization program, namely the potential of schools and regions combined with the implementation of teaching factory-based learning.

The implementation of the teaching factory in vocational schools is still not maximized. It can be seen from the percentage of the number of schools that implement teaching factory is still low. There are two types of teaching factory implementation in Vocational Schools, namely the implementation of the teaching factory referring to the teaching factory parameters, the teaching factory implementation not referring to the teaching factory parameters. Schools that carry out teaching following the parameters of the teaching factory receive technical guidance from the education office. In contrast, schools that carry out teaching factories do not refer to the existing parameters because these schools have not received technical guidance. Other schools that have not implemented teaching factory learning carry out 
learning with competency achievement and have production units where the products produced are not included in the learning process.

Surveys conducted on SMKs that have not implemented Teaching Factory are 1). Do not know how to carry out Teaching Factory, what must be prepared and must be done. 2) Do not understand the product that must be developed 3) What should be done in curriculum synchronization 4) what parameters of the teaching factory should be prepared. When viewed from human resources, curriculum, workshops, management, and the potential of the school area, it is possible to implement a Teaching Factory. A study on the management of teaching factories based on the curriculum and the potential of schools and regions needs to be carried out as a reference for how SMKs will start organizing and managing teaching factories to become independent schools that can produce ready graduates to enter the world of work. It is necessary to conduct training on the development of teaching factories based on local wisdom.

In implementing Teaching Factory learning, key activities need to be emphasized: Product Based Education, Block Scheduling, Job-sheet application, and Corporate Culture Enforcement [1]. These four key activities can run if they are supported by good school management, external relations, government regulations, and support from industry. Some SMKs have successfully implemented Teaching Factory learning. However, some SMKs have tried but stopped on the road. The teaching factory management procedures need to be studied to develop a model that can be applied to vocational schools that want to apply Teaching Factory learning [2].

\section{LITERATURE REVIEW}

\subsection{Teaching Factory}

The teaching factory is a new scheme for improving learning efficiency. Teaching factory is a two-way communication that can create mutually beneficial synergies between academia and industry, enabling the exchange of knowledge and work experience. Teaching factories can adapt theoretical knowledge, research, and innovation. A teaching factory refers to projects related to industry and implemented in real industries. Thus the teaching factory combines the components of the didactic and industrial environment. A teaching factory is a nongeographical learning space facilitated by state-of-the-art ICT and industrial didactic equipment, operating as a two-way channel of knowledge communication [4]. Furthermore, a teaching factory learns based on modern practices and facilities to realize industrial products. Students learn in a practice room, which is conditioned according to a real workplace, intending to produce goods or services, with time limits, work procedures, work procedures according to the standards applicable in the workplace. The concept of learning is to produce products accepted by the market or economic value [3]. A teaching factory is an industrial project that aims to provide a real product realization experience. Teaching factory is a learning method that integrates two environments (the school environment and the industrial environment) in student learning activities to produce useful products and have a selling value that can be accepted by the market, which refers to quality and efficiency applied by industry. Related to this, in practice, the teaching factory requires management. Management is planned, organized, implemented, and evaluated. Therefore, management is needed in the management of the teaching factory. Production is carried out according to the production flow, so a wellorganized workshop is needed. To produce products worth selling, the HR school must have industrial partners who work together in management, product planning, and product marketing.

\subsection{Training}

Training is the process by which people achieve specific abilities to help achieve organizational goals. Training is more likely to be short-term oriented, training affects performance, and if the training conducted by the company is successful, employee performance will increase by itself [4]. Training is a learning process that emphasizes practice rather than theory carried out by someone who works or a group of work units using an adult learning approach (andragogy) to improve work abilities and skills.

Training is teaching or giving experience to someone to develop behavior (knowledge, skills, attitudes) to achieve something desired [5]. Training is a learning effort organized by organizations (government agencies, non-governmental organizations, companies, etc.) to meet needs or achieve organizational goals [6].

According to Edwin B. Flippo, reveals that "Training is the act of increasing the knowledge and skills of an employee for doing a particular job." specific jobs). Simamora, defines training as a series of activities designed to improve skills, knowledge, experience, or change an individual's attitude.

The principles of exercise are: 1) Exercise is only done with the intention of training skills. Exercises are not carried out on understanding, attitudes, and appreciation. 2) Participants realize that the exercise is meaningful for their lives. 3) Exercises must be carried out on things that participants have obtained, for example: Memorizing facts and newly learned skills. 4) Exercise functions as a diagnosis through reproducing efforts to read many times, making corrections for errors that arise. Exercise is also self-guidance and develops 
understanding and control. 5) The exercise is carried out in the following stages: first, practice to get accuracy, then between the two, look for a balance. 6) The exercises are divided into several short training periods, such as mastery and recalling learning outcomes. 7) Exercise activities should be lively, engaging, and fun. 8) Exercise should not be considered as a side effort to be done casually incidentally. 9) Practice can achieve progress thanks to perseverance and high discipline. 10) The exercise carried out is more successful if the emotional element is reduced as much as possible [7]. Skills training includes sequential events or continuous processes with strengths and limits that can be determined. According to him, there are nine training steps, namely: (1) determining training needs, (2) methods of giving instructions, (3) preparing job training programs, (4) training evaluation plans, (5) pre-training steps, (6) instructions, (7) steps after training, (8) feedback on the results of the exercise, and (9) management evaluation.[8].

\subsection{Response}

The response is the reinforcement of behavior that can increase the likelihood of the behavior returning. The response comes from the word response, which means a reply or response (reaction). The response is a psychological term used to describe reactions to stimuli received by the five senses. The things that support and underlie the size of response are attitudes, perceptions, and participation. One's attitude precedes the response. Attitude is a person's tendency or willingness to behave when faced with a particular stimulus. In general, it can be said that three factors influence a person's response, namely: the person concerned, the response target in the form of objects or events, and situational factors. Participants' responses were shown from the participants' learning outcomes. These positive responses could be seen from increased learning outcomes on understanding the material presented by the instructor because they were happy to attend the training. Negative responses were marked by decreased results or unable to understand the material and instructors.

\section{METHODOLOGY}

This type of research is quantitative descriptive. The research subjects are vocational schools in East Java that have not implemented a teaching factory. The data collection method used a questionnaire with a Linkert scale, 1-5. The data analysis technique uses the mean or average.

\section{RESULTS}

\subsection{Implementation of Training}

The following is data on the implementation of the training. The implementation of the training consists of 5 aspects: the suitability of the training objectives, training materials, availability of time, and training methods and training implementation.

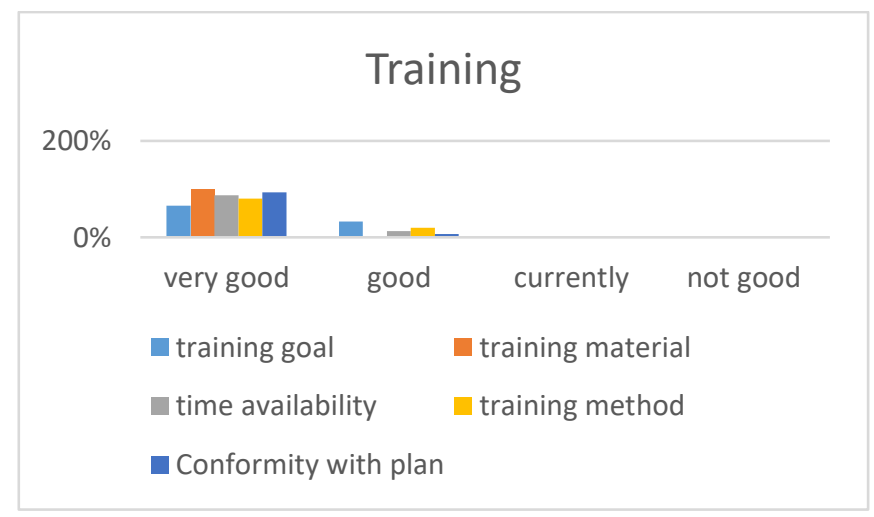

Figure 1 Implementation of Training

The data shows that $66 \%$ of the training participants said it was very good, according to the objectives and $33 \%$ said it was good; $100 \%$ of participants stated that the training material was very good; $87 \%$ of the training participants said the time available was very good, and $13 \%$ of the participants said it was good; $80 \%$ of the training participants said the training method was very good and $20 \%$ said it was good; The training according to the plan was implemented very well $93 \%$ and $7 \%$ good.

If the average percentage is calculated, the training is included in the very good category. The training is carried out following the objectives, namely, to train the teaching factory, the training materials are following the teaching factory parameters, the time provided in training is following the ability of the trainees to participate in the training, the training method is straightforward to follow, and the training is as planned.

The training objectives are very good. The training objectives begin by analyzing the training needs in several schools and observing the condition of the schools, compared to the conditions of schools that have implemented teaching factories. The results of the analysis are synchronized with the training needs and objectives. This way of formulating goals is very appropriate because it can accommodate all needs. After the research objectives are formulated, analyze the study materials from the literature and the facts in the teaching factory. The material obtained was developed by the stages of compiling the teaching factory and grouped the parameters of the teaching factory. Thus the material presented is very good. Implementing the teaching factory training by the specified time is very important to 
pay attention to in the process of implementing time management. Each activity refers to the discipline of the use of time. Time management allows surviving to achieve success [9].

\subsection{Planning Management}

The following is data on the results of the management planning training. There are two aspects of planning management, namely compiling the organization and making job descriptions.

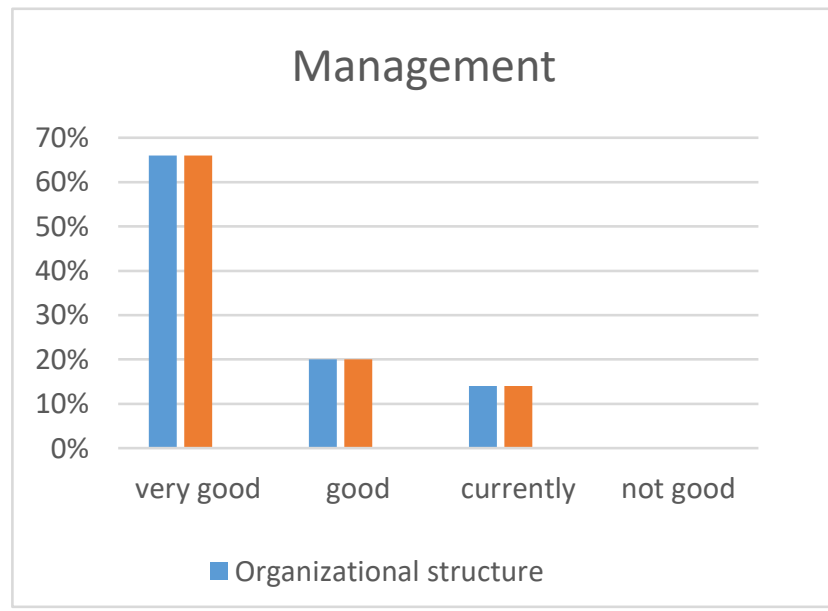

Figure 2 Planning Management

The data shows that the management plans prepared by the participants in organizing the organization and making job descriptions are $66 \%$ very good, $20 \%$ good and $13 \%$ quite good.

Planning management refers to school management. Teaching factory management involves school leaders, industry teachers in the field of study, and laboratory assistants in preparing the organizational structure. Organizational structure refers to the division of tasks, grouping, and coordination [10]. Job descriptions are arranged according to the division of tasks.

\subsection{Planning a Lab/Workshop}

The following is data from the training results in planning a lab/workshop: layout, workshop rules, and compiling occupational safety and health.

The data shows: the workshop layout planned by the participants was $47 \%$ very good, $33 \%$ good and $20 \%$ quite good. The rules/regulations made by the participants showed $67 \%$ very good, $20 \%$ good and $13 \%$ quite good. Meanwhile, $60 \%$ of work safety and security is very good, $27 \%$ is good and $13 \%$ is quite good.

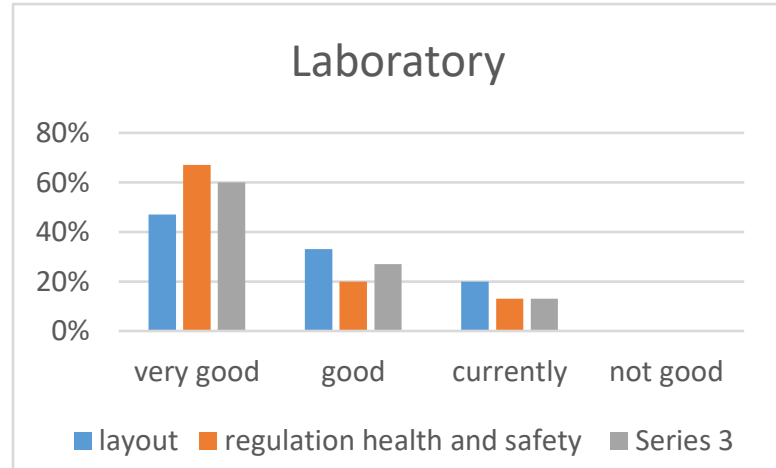

Figure 3 Planning a Laboratory

The arrangement of the lab/workshop is made by analyzing the condition of the lab, the lab area, the type of equipment, and the tools needed. Training participants plan workshop labs according to the conditions of their respective schools. Lab arrangement or layout refers to the order of competency levels. Order of competency levels, regular and continuous [11].

\subsection{Planning Lessons}

The following data shows the training results on learning planning, which consists of 2 aspects, namely, planning industrial-based learning and preparing learning tools.

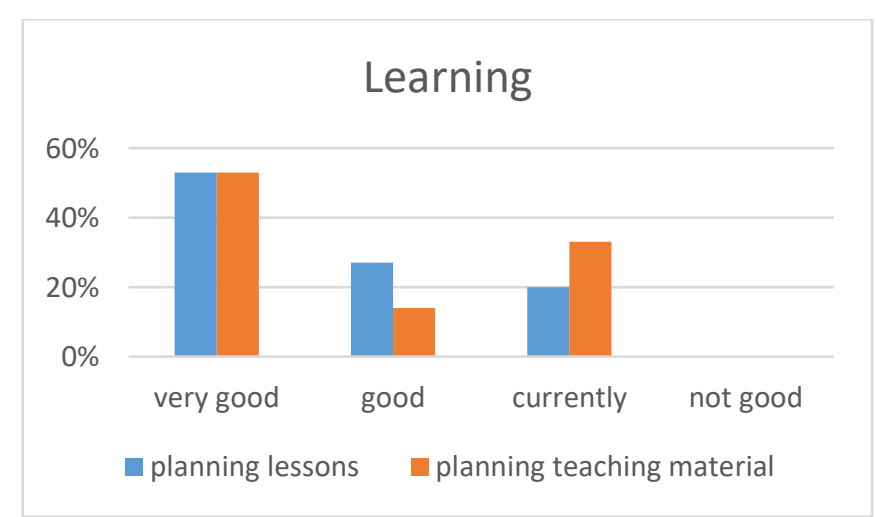

Figure 4 Planning Lessons

The data shows that $53 \%$ of the training participants planned the lesson very well, $27 \%$ well and $20 \%$ quite well. In compiling learning tools $53 \%$ are very good, $14 \%$ are good and $33 \%$ are quite good.

\subsection{Planning Products from Local Potential}

The following is data on product planning training results covering products referring to the curriculum regional potential, industrial products, and worthy of sale. 


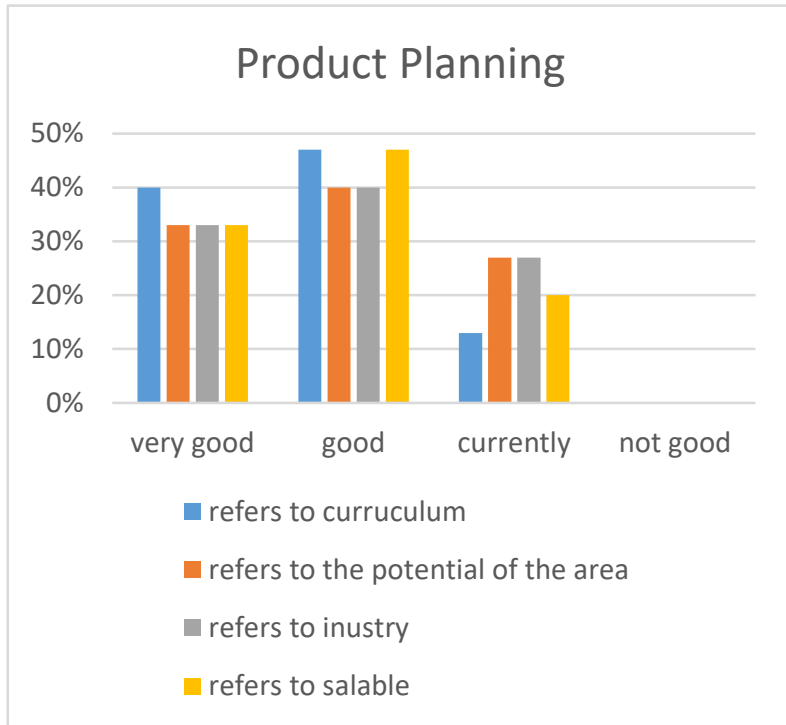

Figure 5 Product Planning

The data shows that the product planned by the trainees refers to the curriculum, $40 \%$ is very good, $47 \%$ is good and $13 \%$ is quite good; product refers to the potential of the region $33 \%$ very good. $40 \%$ good. And $27 \%$ is pretty good; product refers to partner industry $33 \%$ very good, $40 \%$ good and $27 \%$ quite good; while the products worth selling are $33 \%$ very good, $47 \%$ good and $20 \%$ quite good.

Product planning is a means of achieving competence. The planned product refers to the curriculum, regional potential, industry, and goods worth selling. Participants plan products so widely, but there are several obstacles in planning products according to regional potential, which must be in sync with industrial products and competencies in the curriculum. The planned product still refers to the curriculum because no appropriate industrial partner is implementing the teaching factory.

Teaching factory development training is beneficial and is a new method of learning, products are planned according to local products, can lift local culture, management of potential products needs to have cooperation with industry, government, and local communities. Teaching factory development training positively impacts participants to improve their interpersonal and technical skills, teamwork, and motivation [12].

Teaching factory development training is beneficial and is a new method of learning. Products are planned according to local products, can lift local culture, and management of potential products needs to cooperate with industry, government, and local communities. Training is the most effective way to motivate and maintain the quality of human resources. [12].

\section{CONCLUSIONS}

The implementation of teaching factory development training refers to the school's needs and objectives. In this case, the formulation of objectives is based on training objectives and analysis of school needs. Therefore, the implementation of the training is carried out very well, the relevance of objectives with the hope that participants can be achieved optimally.

The implementation of the training use training methods that refer to the training objectives and training materials. Workshop training methods can create a participatory learning atmosphere that emphasizes the learning process. Workshops on management planning, planning lab workshops, planning lessons, and planning products can be done well.

\section{REFERENCES}

[1] ATMI, (2018). Konsep Teaching Factori (Bahan paparan rembug vokasi nasional 2018).

[2] Bakrun, M., Pantjastuti, S. R., Hendarman, H., \& Sutanto, S. (2018). Kilasan Dua Tahun Revitalisasi Sekolah Menengah Kejuruan. Jakarta: Direktorat Pembinaan Sekolah Menengah Kejuruan.

[3] Lamancusa, J. S., Zayas, J. L., Soyster, A. L., Morell, L., \& Jorgensen, J. (2008). The Learning Factory: Industry-Partnered Active Learning. Journal Of Engineering Education, 97(1), 1-15.

[4] Dessler, G. (2005). Manajemen Sumber Daya Manusia (Edisis kesepuluh).New Jersey: PrenticeHall.

[5] Marzuki, Saleh. H.M. (2010). Pendidikan Nonformal. Dimensi dalam Keaksaraan Fungsional, Pelatihan, dan Andragogi. Bandung: Penerbit Rosda.

[6] Friedman, MM, Bowden, O \& Jones, M. 2010. Buku Ajar Keperawatan Keluarga : riset, teori, \& praktik ; alih bahasa, Achir Yani S. Hamid...[et al.]; editor edisi bahasa Indonesia, Estu Tiar, Ed. 5. Jakarta : EGC.

[7] Hamalik, Oemar. 2007. Manajemen Pelatihan Ketenagakerjaan Pendekatan Terpadu Pengembangan Sumber Daya Manusia. Jakarta : Bumi Aksara.

[8] John H Procton \& William M. Thornton. 1983. Latihan Kerja. Jakarta: PT Bina Aksara.

[9] Antonius Atosökhi Gea (2014) TIME MANAGEMENT. HUMANIORA Vol.5 No.2 Oktober 2014: 777-785.

[10] Aquinas, P. G. (2008). Organization Structure And Design. New Delhi: Excel Books India. 
[11] Ghufron, A., Suwarna, Sudiyatno, Sunaryo, S., Andayani, S., Setiadi, B. R., \& Ismara, I. (2019). Modernisasi Bengkel Laboratorium Kejuruan Abad 21. Direktorat Pembinaan Sekolah Menengah Kejuruan Direktorat Jenderal Pendidikan Dasar Dan Menengahkementerian Pendidikan Dan Kebudayaan.

[12] Kate Hutchings, Cherrie J. Zhu, Brain K, Cooper, Yiming Zhang and Sijun Shao (2009): "Perceptions of the effectiveness of training and development of "grey-collar" workers in the People's Republic of China". Human Resource Development International, Vol.12, No.3, pp 279-296. 